
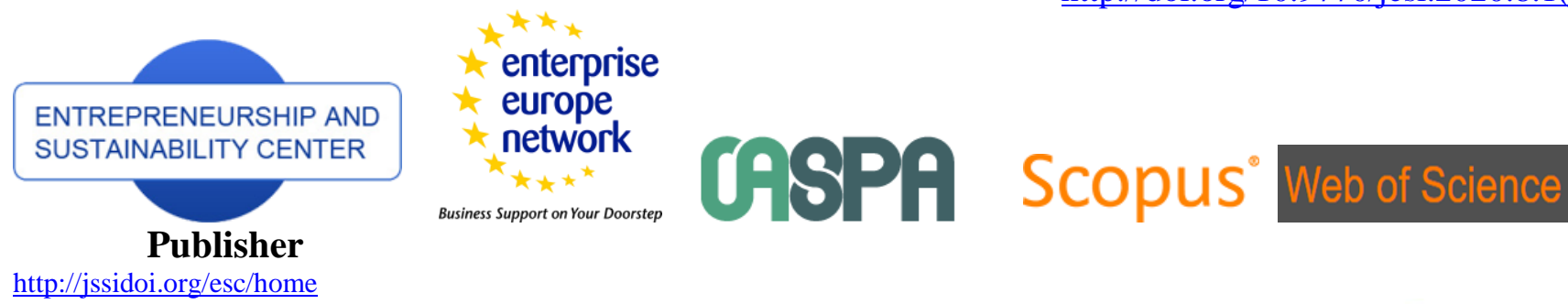

$\underline{\mathrm{http}: / / \text { jssidoi.org/esc/home }}$

\title{
PERCEIVED INFLUENCE OF CORPORATE SOCIAL RESPONSIBILITY ON CONSUMER LOYALTY: THE ROLE OF ETHICAL IDEOLOGY
}

\author{
Daiva Beniulytė ${ }^{1}$, Beata Šeinauskienė ${ }^{2}$, Aušra Rūtelioné ${ }^{3}$ \\ ${ }^{1,2,3}$ Kaunas University of Technology, School of Economics and Business, Gedimino str. 50, Kaunas, Lithuania \\ I․ㅡiul.daiva@gmail.com; 2 beata.seinauskiene@ktu.lt; ${ }^{3}$ ausra.rutelione@ktu.lt
}

Received 15 December 2019; accepted 25 May 2020; published 30 September 2020

\begin{abstract}
This study explored how different types of perceived corporate social responsibility serve to affect customer loyalty, and how consumer ethical ideologies affect perceived corporate social responsibility. The empirical research analysis reveals that respondents are more often characterised by an ethical ideology of idealism, and that they are most aware of any corporate social responsibility (CSR) that is consumer-orientated. In addition, it has been found that the perceived CSR, which focuses on the public, has a significantly lower impact, while the impact of the perceived employee-orientated CSR is statistically significant only in respect to repeat purchases.
\end{abstract}

Keywords: CSR; ethical ideologies; consumer loyalty

Reference to this paper should be made as follows: Beniulytė, D., Šeinauskienè, B., Rūtelionè, A. 2020. Perceived influence of corporate social responsibility on consumer loyalty: the role of ethical ideology. Entrepreneurship and Sustainability Issues, 8(1), 291-300. http://doi.org/10.9770/jesi.2020.8.1(20)

JEL Classifications: M31, M14

\section{Introduction}

Research shows that consumers are characterised by different ethical ideologies that influence their decisionmaking. The corresponding values between consumer and company have been widely discussed in academic literature, and ambiguous results show that the relevancy of such values leads to a more desirable consumer attitude and behaviour. In theory, the argumentation of the effect of value-matching in terms of desirable consumer behaviour could be extrapolated to the level of compatibility between consumer and corporate values. Nevertheless, it should be noted that the effect of matching consumer and corporate values in terms of consumer loyalty has not been extensively investigated by the ethical ideologies of the consumer (representing certain ethically-based values) and those values of the company that are disclosed, including the company's activities through corporate social responsibility. The identified knowledge gap raises the need for further research.

Morality and ethics have a long history of discourse in a variety of contexts, including philosophy, religion and, more recently, business (Kolodinsky, Madden, Zisk and Henkel, 2010). Researchers (Ellen, Webb and Mohr, 


\section{ENTREPRENEURSHIP AND SUSTAINABILITY ISSUES}

ISSN 2345-0282 (online) http://jssidoi.org/jesi/

2020 Volume 8 Number 1 (September)

http://doi.org/10.9770/jesi.2020.8.1(20)

2006; Valentine \& Bateman, 2011; Leonidou, Leonidou and Kvasova, 2013); Palihawadana, Oghazi and Liu, 2016; Arli \& Leo, 2017) are increasingly focusing on the analysis of indirect connotations of perceived CSR and consumer loyalty, but the factors that are associated with consumer characteristics are rarely taken into account. In scientific marketing literature, the ethical ideologies of consumers are mainly analysed by taking into account the theoretical basis offered by Forsyth (1980), in which consumer behaviour is analysed from the point of view of idealism (in other words it is in keeping with moral values while making ethical decisions) and relativism (when moral actions are taken with a dependence upon the nature of the situation and the people involved). Valentine \& Bateman (2011) analysed the influence of idealism, relativism, and consumer-perceived moral intensity on consumer decisions in relation to ethical issues and ethical-based intentions within a social context. Arli and Pekerti (2016) explored how the ethical ideologies of idealism and relativism, religion and belonging to a certain generation of consumers serves to determine decisions that are driven by the consumer ethic. Later, Arli and Leo (2017) conducted a study which evaluated the ethical decision-making phenomenon of individuals that can be characterised by the aforementioned ethical ideologies as affected by the factors of guilt and self-control. Palihawadana, Oghazi and Liu (2016) explored how CSR as perceived by consumers affects the evaluation of goods that are offered by companies in developing Vietnam, with the ethical ideology (idealism and egoism) of consumers being included in the study.

The results that were obtained by the aforementioned authors have revealed a strong positive relation between idealism and consumer concerns about the unethical nature of marketing activities. From this it was possible to identify a direct negative relation between corporate unethical marketing activities and consumer confidence in a company. Research shows that the loss of consumer confidence has a direct impact on their behavioural changes in terms of repeated purchases, consumer recommendations, and loyalty. In addition, Leonidou, Leonidou and Kvasova (2013), when basing this on the results of the study, also identified the relation between idealism and egoism, and concluded that individuals with a high level of idealism also change the attitude of those who lean towards egoism.

It is noted that the relation between consumer moral ideologies and company values which is indirectly affected through the activities of companies, such as CSR, and its impact on consumer loyalty have been investigated only indirectly and in a highly fragmented fashion. It has been noticed that the ethical attitudes of consumer idealism and egoism have an impact not only on the perceived CSR, but that they also are reflected in consumer behaviour when making decisions in terms of quality (specifically the quality and ethical value ratio), determining the level of trust in the company and behaviour towards it when that company applies unethical marketing solutions.

The present study addresses this research gap by exploring how different types of perceived corporate social responsibility serve to affect customer loyalty and how consumer ethical ideologies serves to affect perceived CSR.

\section{Literature review and hypotheses}

\subsection{The relationship between the ethical ideologies of consumers and perceived CSR}

The authors of this study take the view that, when making consumer-related decisions and choosing companies to whom they will express their loyalty, consumers base their decisions on the company's perceived corporate social responsibility, with such a choice being influenced by the ethical ideologies of idealism and egoism that are specific to the consumer. Many authors agree that the ethical ideologies of consumers (idealism and egoism) are an important factor which serves to influence the perception by consumers of CSR and their decision-making (AlKhatib, Stanton \& Rawwas, 2005; Ellen, Mohr, and Webb, 2006; Leonidou, Leonidou and Kvasova, 2013). It has been observed that the ideologies of idealism and egoism have been considered in scientific sources as being highly fragmented. The choice of the aforementioned ideologies is also based on research that has been carried out by Palihawadana, Oghazi and Liu (2016), which analysed the relation between the ethical ideologies of 


\section{ENTREPRENEURSHIP AND SUSTAINABILITY ISSUES}

ISSN 2345-0282 (online) http://jssidoi.org/jesi/

2020 Volume 8 Number 1 (September)

http://doi.org/10.9770/jesi.2020.8.1(20)

idealism and egoism on the one hand and CSR on the other, and managed to identify their different levels of impact on the consumer perception of CSR. Therefore it is important to evaluate the impact of ethical ideologies by incorporating the ethical ideologies of idealism and egoism into the conceptual model of research.

Research shows that individuals who can be characterised by the ideology of idealism find it important to discover solutions that will have positive effects and can benefit all parties. Consumers who confess this ideology follow moral rules when making decisions and seek to solve ethical issues that are likely to lead to a positive attitude towards CSR due to matching moral values. The positive influence of idealism on consumer perception of CSR was empirically determined by Forsyth (1980), Kolodinsky, Madden, Zisk and Henkel (2010), Leonidou, Leonidou and Kvasova (2013) and Palihawadana, Oghazi and Liu (2016). The authors noted that the positive relationships were determined by the ethical ideology of idealism and the inherently common nature of CSR, as reflected in a respect for ethical and moral values. Therefore, we hypothesise that:

H1: Idealism has a positive impact on CSR as perceived by consumers

\subsection{The ethical ideology of egoism and CSR as perceived by consumers}

Research shows that consumers who can be characterised by the ethical ideology of egoism tend to accept only those corporate socially responsible initiatives that, in essence, strictly meet their personal needs, do not contradict their interests, and deliver the most personal benefit. The results of empirical research by Palihawadana, Oghazi and Liu (2016) revealed that users who are prone to egoism support only those CSR activities in which they see direct personal gain. Russell and Russell (2010), however, have found that consumers who can be characterised by egoism are more focused on locally-developed CSR initiatives that directly affect their daily lives. Therefore we hypothesise that:

H2: Egoism has a negative impact on CSR as perceived by consumers

\subsection{The impact of the perceived CSR on consumer loyalty}

The analysis of research on the perceived impact of CSR in terms of consumer loyalty has revealed that even though the aforementioned relationship has widely been analysed, the research results are inconsistent and can be characterised as providing different results due to different perceptions of CSR and the conceptualisation of the consumer loyalty phenomena. In work in which the relationship was assessed between perceived CSR and consumer loyalty, the results have been identified which indicate that CSR has a positive impact on brand recognition, company reputation, loyalty, and confidence in the company. However, it is assumed that different forms of CSR have a positive impact on consumer loyalty and areas in which it is expressed - the attitude towards the company, the verbal recommendation, and the intention to purchase repeatedly. In aiming to identify which dimension of perceived CSR has the greatest level of impact in terms of consumer loyalty, the classification will be applied of consumer-perceived CSR that is being offered by Marquina \& Vasquez (2013). This involves corporate social responsibility which is orientated towards the public, consumers, and employees.

Maignan \& Ferrell (2001) found that consumers are attentive to the physical and tangible aspects of corporate social responsibility, which are usually associated with the levels of quality of products or services, innovation, and the compliance of standards. When taking this into account, a significant influence by perceived CSR through perceived quality was identified by Wan, Poon and Yu (2016). It was found that CSR indirectly influences the purchasing intentions of and recommendations by consumers. The influence of CSR through perceived quality of service upon consumer loyalty, however, was also evaluated by Mandhachitara and Poolthong (2011), whose research showed that there is a positive impact in terms of the perceived CSR in relation to consumer loyalty and repeat purchases. It has been noticed that research shows ambiguous results in terms of any positive relation between perceived quality and consumer loyalty. When taking into account the aforementioned relation, it is 


\section{ENTREPRENEURSHIP AND SUSTAINABILITY ISSUES}

ISSN 2345-0282 (online) http://jssidoi.org/jesi/

2020 Volume 8 Number 1 (September)

http://doi.org/10.9770/jesi.2020.8.1(20)

assumed that perceived CSR which is orientated towards consumers should also be positively linked to consumer loyalty. Therefore we hypothesise that:

H3: perceived consumer-orientated CSR has a positive impact on consumer loyalty;

$H 3 a$ : perceived consumer-orientated CSR has a positive impact on consumer attitude;

$H 3 b$ : perceived consumer-orientated CSR has a positive impact on verbal recommendations;

H3c: perceived consumer-orientated CSR has a positive impact on repeat purchases.

\subsection{The impact of perceived employee-orientated CSR on consumer loyalty}

The impact of this construct in terms of consumer loyalty is based on the fact that, within the context of socially responsible initiatives, companies indirectly communicate their values which their own employees cherish and pass on to consumers. According to Peloza \& Shang (2011), the publicised CSR initiatives have the potential to establish a stronger relationship with a stakeholder, in this case this being the consumer, and thereby form a positive image for the company. For this reason, consumer engagement and decision-making based on ethical values have a positive impact upon their behaviour and expressed loyalty. Marquina \& Vasquez (2013) discussed the impact that employee-orientated CSR has on consumer loyalty, basing their thoughts on research, revealing that while developing corporate social responsibility and company-employee relationship, that company also has a positive impact upon consumer behaviour at the same time. Therefore we hypothesise that:

H4: perceived employee-orientated CSR has a positive impact on consumer loyalty;

H4a: perceived employee-orientated CSR has a positive impact on consumer attitude;

H4b: perceived employee -orientated CSR has a positive impact on verbal recommendations;

H4c: perceived employee -orientated CSR has a positive impact on repeat purchases.

\subsection{The impact of perceived society-orientated CSR on consumer loyalty}

Research shows that society-orientated CSR and its forms such as support, investment in infrastructure, or support for social and cultural events, leads to the creation of positive associations towards the company and its product which serve to influence consumer loyalty. Henderson (2007) observes that the dissemination of information regarding socially-responsible activities which are carried out by companies has a significant level of impact on the positive attitude of consumers towards the company. Abdeen, Rajah and Gaur (2016) have also identified CSR initiatives as having a positive impact on consumer intentions to support a company, to promote purchasing behaviour, and to create a sense of trust and loyalty towards the company. Based on the aforementioned insights, it can be assumed that the more favourably consumers view different forms of a company's society-orientated social responsibility, the more loyal they are to that company. Therefore we hypothesise that:

H5: perceived society-orientated CSR has a positive impact on consumer loyalty;

H5a: perceived society -orientated CSR has a positive impact on consumer loyalty;

H5b: perceived society -orientated CSR has a positive impact on verbal recommendations;

H5c: perceived society -orientated CSR has a positive impact on repeat purchases.

All hypotheses that have been formed in this section, and which serve to outline the relation between consumer ethical ideologies, perceived CSR, and consumer loyalty, are visually depicted in a conceptual context, a model of ethical ideologies, and the impact that the perceived CSR has on consumer loyalty (Figure 1). 
ENTREPRENEURSHIP AND SUSTAINABILITY ISSUES

ISSN 2345-0282 (online) http://jssidoi.org/jesi/

2020 Volume 8 Number 1 (September)

http://doi.org/10.9770/jesi.2020.8.1(20)

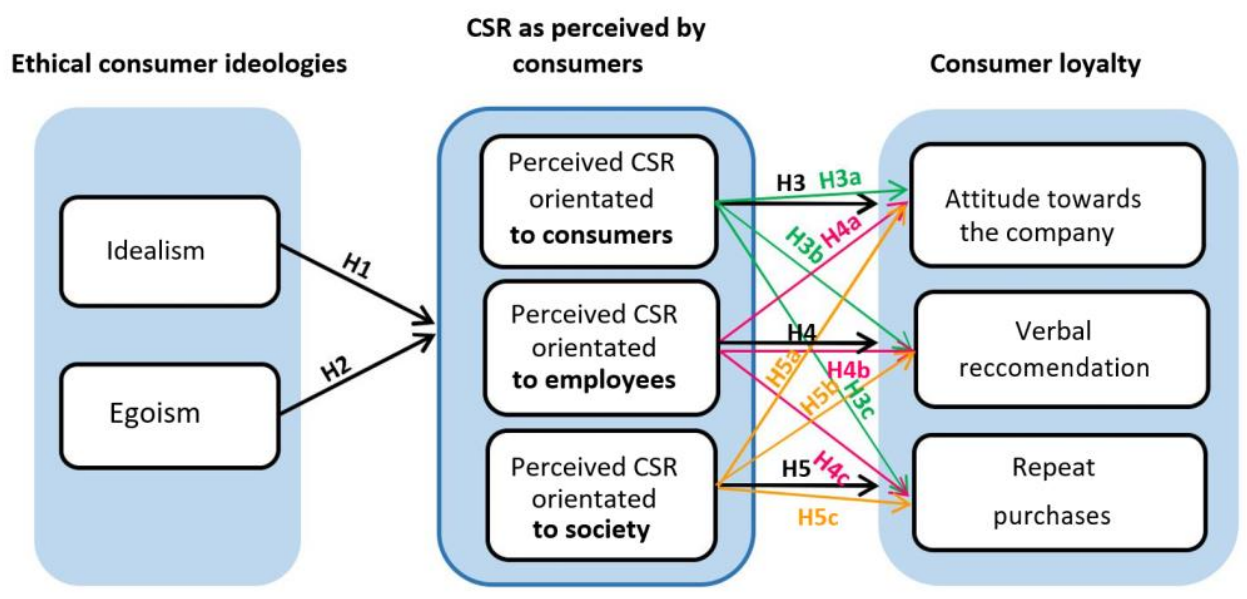

Fig 1. The conceptual model of the perceived CSR influence on consumer loyalty within the context of consumer ethical ideologies

\section{Research methodology}

In order to explore how different types of perceived corporate social responsibility affect customer loyalty and how consumer ethical ideology affects perceived CSR, we carried out a survey (between July 2019 and September 2019). The quantitative exploratory research design was adopted to test the conceptualized relations between ethical consumer ideologies, perceived CSR and consumer loyalty. Questionnaires were distributed to Lithuanian users of mobile communications, using a convenience sampling technique. The results were collected from Lithuanian users of mobile communications services. A total of 391 valid survey responses were utilised for the analysis. We addressed the non-response bias through the t-test. There was no significant difference in scores for early and late responses and no significant differences between respondents and non-respondents with regard to age or gender. We carried out two different tests in order to examine a common method bias. In order to be able to measure the constructs we used previously established and validated scales. The five-point Likert-type scales by Pérez \& Bosque (2015) were used to capture the CSR orientation towards consumers, employees, and society. The five-point Likert-type scales by Leonidou, Leonidou and Kvasova (2013) were adopted to measure the ethical ideology of idealism and egoism. The five-point Likert-type scales by Moreira \& Moutinho (2016) and Fatma, Khan and Rahman (2016) were adopted to measure the positive attitude towards the company. The fivepoint Likert-type scales by Pérez \& Bosque (2015) and Fatma, Khan and Rahman (2016) were used to capture positive verbal recommendation and repeat-purchases.

\section{Data analysis and results}

The analysis of the results from the factor analysis showed that, in all cases, KMO values are prevalent that are higher than 0.4 and with Bartlett's sphericity criterion the figures are no higher than 0.01 . As a result, it has been concluded that the analysis that has been carried out is effective and useful, and that the constructs of the research model that have been developed and the variables belonging to them are suitable for further analysis.

The descriptive analysis of variables in terms of consumer ethical ideologies that was carried out, plus the perceived CSR and consumer loyalty constructs, revealed that respondents to the survey can often be characterised by an ethical ideology of idealism and, when taking into account the average values for answers to the questions, it was found that respondents are most aware of CSR where it is consumer-orientated. The KruskalWallis tests that have been carried out, based on grouping variables of gender, age, and mobile operator, revealed statistically significant differences between the construct variables that were included in the study. These are 


\section{ENTREPRENEURSHIP AND SUSTAINABILITY ISSUES}

ISSN 2345-0282 (online) http://jssidoi.org/jesi/ 2020 Volume 8 Number 1 (September) http://doi.org/10.9770/jesi.2020.8.1(20)

likely to explain standard deviations in respondent responses. Whilst analysing the results of the tests that were carried out, it was established that women can be characterised by their possessing a more ethical ideology of idealism more often than do men. They also express a higher level of loyalty and a better understanding of socially responsible corporate initiatives.

A correlation analysis was carried out in order to identify the relationship between the ethical ideologies of consumers, their perceived CSR, and consumer loyalty. Summary results for multiple regression analysis which was used to measure the impact of various dimensions of consumer-perceived CSR on consumer loyalty and its forms, such as attitude towards the company, positive verbal recommendation, and repeat purchases, which were represented by all statistically significant correlations, are presented in the table below (Table 1).

Table 1. The results of testing the hypotheses

\begin{tabular}{|c|c|c|c|c|c|}
\hline Independent variables & Dependent variables & Hypothesis & $\begin{array}{l}\text { Has the hypothesis been } \\
\text { confirmed? }\end{array}$ & $\mathrm{R}^{2}$ & Beta \\
\hline Idealism & Perceived CSR & $\mathrm{H} 1$ & Yes & 0.140 & $0.272 * *$ \\
\hline Egoism & Perceived CSR & $\mathrm{H} 2$ & Yes & 0.209 & $-0.106^{*}$ \\
\hline \multirow{4}{*}{$\begin{array}{l}\text { Perceived consumer- } \\
\text { orientated CSR }\end{array}$} & Consumer loyalty & $\mathrm{H} 3$ & Yes & 0.546 & $0.867 * *$ \\
\hline & Attitude & $\mathrm{H} 3 \mathrm{a}$ & Yes & 0.564 & $0.643 * *$ \\
\hline & Verbal recommendation & $\mathrm{H} 3 \mathrm{~b}$ & Yes & 0.692 & $0.563 * *$ \\
\hline & Repeat purchases & $\mathrm{H} 3 \mathrm{c}$ & Yes & 0.377 & $0.352 * *$ \\
\hline \multirow{4}{*}{$\begin{array}{l}\text { Perceived employee- } \\
\text { orientated CSR }\end{array}$} & Consumer loyalty & $\mathrm{H} 4$ & No & 0.546 & 0.062 \\
\hline & Attitude & $\mathrm{H} 4 \mathrm{a}$ & No & 0.564 & 0.044 \\
\hline & Verbal recommendation & $\mathrm{H} 4 \mathrm{~b}$ & No & 0.692 & 0.027 \\
\hline & Repeat purchases & $\mathrm{H} 4 \mathrm{c}$ & Yes & 0.377 & $0.098 *$ \\
\hline \multirow{4}{*}{$\begin{array}{l}\text { Perceived society- } \\
\text { orientated CSR }\end{array}$} & Consumer loyalty & $\mathrm{H} 5$ & Yes & 0.546 & $0.157 * *$ \\
\hline & Attitude & $\mathrm{H} 5 \mathrm{a}$ & Yes & 0.564 & $0.092 * *$ \\
\hline & Verbal recommendation & $\mathrm{H} 5 \mathrm{~b}$ & Yes & 0.692 & $0.141^{*}$ \\
\hline & Repeat purchases & $\mathrm{H} 5 \mathrm{c}$ & Yes & 0.377 & $0.200 * *$ \\
\hline
\end{tabular}

$N=391$. Level of significance: $* * p<0.001 ; * p<0.05 ;$ with control variables being gender, age, and phone service provider.

\section{Conclusions and further research directions}

Having analysed research results regarding the influence of the perceived social responsibility of Lithuanian telecommunications companies (mobile operators) in terms of the loyalty of consumers within the context of ethical ideologies, a model can be provided which is based upon empirical research. All hypotheses in the applied conceptual model have been confirmed and only three of them had a statistically insignificant factor (perceived employee-orientated CSR and its statistically insignificant impact on consumer loyalty, attitude, and verbal recommendation). At that time, the influence on employee-orientated CSR was determined only after repeat purchase. The results of research that was carried out by Jensen, Annan-Diab and Seppala (2018) in a very similar context - the telecommunications industry in Europe - did not reveal any clear impact of perceived employeeorientated CSR on repeat purchases. The research that was conducted by Pérez and Bosque (2015) also showed that the impact of employee-orientated CSR is not always identifiable and can be determined by other factors which may be influencing this link.

A summary of hypotheses is provided in Table 2 which shows that these hypotheses were formed within the conceptual model of the study and their established relationships in the empirical model. The table also shows that perceived society-orientated CSR can be characterised by a relatively weak relationship. According to Forehand \& Grier (2003), the aforementioned weakness of the connection could be caused by the increasing scepticism of consumers regarding socially responsible initiatives. In addition, it has been noticed that consumers are not 
informed about corporate socially responsible activities in society. Lauritsen \& Perks (2015) propose an assumption that consumers do not actively seek information regarding CSR on their own, and instead tend to understand CSR through inclusive communication and interactivity. They also suggest that in order to generate benefits from CSR, it is first and foremost necessary to communicate it well to the target audience.

Table 2. A summary of the hypotheses and the relationships in the empirical model

\begin{tabular}{|c|c|c|c|}
\hline \multicolumn{2}{|r|}{ Hypotheses } & $\mathrm{R}^{2}$ & $p$ \\
\hline $\mathrm{H} 1$ & $\begin{array}{l}\text { Idealism has a positive impact on CSR as } \\
\text { perceived by consumers }\end{array}$ & 0.140 & $0.272 * *$ \\
\hline $\mathrm{H} 2$ & $\begin{array}{l}\text { Egoism has a negative impact on CSR as perceived } \\
\text { by consumers }\end{array}$ & 0.209 & $-0.106^{*}$ \\
\hline $\mathrm{H} 3$ & $\begin{array}{l}\text { Perceived consumer-orientated CSR has a positive } \\
\text { impact on consumer loyalty }\end{array}$ & 0.546 & $0.867 * *$ \\
\hline $\mathrm{H} 3 \mathrm{a}$ & $\begin{array}{l}\text { Perceived consumer-orientated CSR has a positive } \\
\text { impact on attitude towards a company }\end{array}$ & 0.564 & $0.643 * *$ \\
\hline $\mathrm{H} 3 \mathrm{~b}$ & $\begin{array}{l}\text { Perceived consumer-orientated CSR has a positive } \\
\text { impact on verbal recommendation }\end{array}$ & 0.692 & $0.563 * *$ \\
\hline $\mathrm{H} 3 \mathrm{c}$ & $\begin{array}{l}\text { Perceived consumer-orientated CSR has a positive } \\
\text { impact on repeat purchases }\end{array}$ & 0.377 & $0.352 * *$ \\
\hline $\mathrm{H} 4$ & $\begin{array}{l}\text { Perceived employee-orientated CSR has a positive } \\
\text { impact on consumer loyalty }\end{array}$ & 0.546 & 0.062 \\
\hline $\mathrm{H} 4 \mathrm{a}$ & $\begin{array}{l}\text { Perceived employee -orientated CSR has a positive } \\
\text { impact on attitudes towards a company }\end{array}$ & 0.564 & 0.044 \\
\hline $\mathrm{H} 4 \mathrm{~b}$ & $\begin{array}{l}\text { Perceived employee -orientated CSR has a positive } \\
\text { impact on verbal recommendation }\end{array}$ & 0.692 & 0.027 \\
\hline $\mathrm{H} 4 \mathrm{c}$ & $\begin{array}{l}\text { Perceived employee -orientated CSR has a positive } \\
\text { impact on repeat purchases }\end{array}$ & 0.377 & $0.098 *$ \\
\hline $\mathrm{H} 5$ & $\begin{array}{l}\text { Perceived society-orientated CSR has a positive } \\
\text { impact on consumer loyalty }\end{array}$ & 0.546 & $0.157 * *$ \\
\hline H5a & $\begin{array}{l}\text { Perceived society -orientated CSR has a positive } \\
\text { impact on attitudes towards a company }\end{array}$ & 0.564 & $0.092 * *$ \\
\hline $\mathrm{H} 5 \mathrm{~b}$ & $\begin{array}{l}\text { Perceived society -orientated CSR has a positive } \\
\text { impact on verbal recommendation }\end{array}$ & 0.692 & $0.141^{*}$ \\
\hline H5c & $\begin{array}{l}\text { Perceived society -orientated CSR has a positive } \\
\text { impact on repeat purchases }\end{array}$ & 0.377 & $0.200 * *$ \\
\hline
\end{tabular}

Based on the recommendations proposed in the study that was carried out by Lii \& Lee (2012), it is suggested that personalised CSR initiatives be carried out that reflect consumer values and lifestyle and thereby enhance the effectiveness of CSR. The author states that, by applying this method, CSR makes it possible to reach a larger part of the target audience and the possibilities in terms of being able achieve a well-defined group of users by exercising CSR initiatives are realistic, although it is necessary to deliberately implement corporate social responsibility.

The research has several limitations. Firstly, a cross-sectional research design, so it is difficult to claim causeeffect inferences. Also findings may not be generalizable to other populations (respondents - users of mobile communications services). The nonprobability sampling has been used as it was not be possible to acquire the sampling frame and ensure that all members of the population had a reasonable opportunity to be invited to participate in the study.

Further directions of research could be based on focusing upon specific consumer characteristics, especially where they are related to consumer values or character features, seeking new insights into the affected perceived 


\section{ENTREPRENEURSHIP AND SUSTAINABILITY ISSUES}

ISSN 2345-0282 (online) http://jssidoi.org/jesi/ 2020 Volume 8 Number 1 (September) http://doi.org/10.9770/jesi.2020.8.1(20)

CSR. In this study, statistically significant differences in perceived CSR and consumer loyalty were also identified, basing them on the aspects of gender and age. According to Leonidou, Leonidou and Kvasova (2013), younger individuals can be characterised as having a lower level when it comes to promoting their ethical values, while older, educated individuals have a higher level of ethics and idealism. Therefore it would be useful to further analyse the perceived CSR in narrower age groups. The empirical study also identified corporate social responsibility as mostly being perceived by female employees, so it would make sense to pay more attention to the causes of this phenomenon and to analyse the factors that ultimately determine the CSR that is perceived by men. As another direction for continuance of this study, the application of this scientific model in other areas of corporate activity could also be possible, provided that those companies that are analysed meet the only criterion that of engaging in social responsibility.

\section{References}

Abdeen, A.; Rajah, E.; \& Gaur, S. S. 2016. Consumers' beliefs about firm's CSR initiatives and their purchase behaviour, Marketing Intelligence \& Planning 34(1): 2-18. https://doi.org/10.1108/mip-06-2014-0107.

Al-Khatib; J. A., D'Auria Stanton; A., \& Rawwas, M. Y. 2005. Ethical segmentation of consumers in developing countries: a comparative analysis, International Marketing Review 22(2): 225-246. https://doi.org/10.1108/02651330510593287.

Arli, D.; \& Leo, C. 2017. Why do good people do bad things? The effect of ethical ideology, guilt proneness, and self-control on consumer ethics, Asia Pacific Journal of Marketing and Logistics 29(5): 1055-1078. https://doi.org/10.1108/apjml-11-2016-0218

Arli, D.; \& Pekerti, A. 2016. Investigating the influence of religion, ethical ideologies and generational cohorts toward consumer ethics: which one matters?, Social Responsibility Journal 12(4): 770-785. https://doi.org/10.1108/srj-08-2015-0112

Ellen, P. S.; Webb, D. J.; \& Mohr, L. A. 2006. Building corporate associations: Consumer attributions for corporate socially responsible programs, Journal of the academy of Marketing Science 34(2): 147-157. https://doi.org/10.1177/0092070305284976

Fatma, M.; Khan, I.; \& Rahman, Z. 2016. How does corporate association influence consumer brand loyalty? Mediating role of brand identification, Journal of Product \& Brand Management 25(7): 629-641. https://doi.org/10.1108/jpbm-07-2015-0932

Foreh, M. R.; \& Grier, S. 2003. When is honesty the best policy? The effect of stated company intent on consumer skepticism, Journal of Consumer Psychology 13(3): 349-356. https://doi.org/10.1207/s15327663jcp1303_15

Forsyth, D. R. 1980. A taxonomy of ethical ideologies, Journal of Personality and Social Psychology 39(1): 175.

https://doi.org/10.1037//0022-3514.39.1.175

Forsyth, D. R. 1992. Judging the morality of business practices: The influence of personal moral philosophies, Journal of Business Ethics: 11(5-6): 461-470. https://doi.org/10.1007/bf00870557

Fukukawa, K.; Balmer, J. M.; \& Gray, E. R. 2007. Mapping the interface between corporate identity, ethics and corporate social responsibility, Journal of Business Ethics 76(1): 1-5. https://doi.org/10.1007/s10551-006-9277-0

Henderson, J. C. 2007. Corporate social responsibility and tourism: Hotel companies in Phuket, Thailand, after the Indian Ocean tsunami, International Journal of Hospitality Management 26(1): 228-239. https://doi.org/10.1016/j.ijhm.2006.02.001

Jensen, B.; Annan-Diab, F.; \& Seppala, N. 2018. Exploring perceptions of customer value: the role of corporate social responsibility initiatives in the European telecommunications industry, European Business Review 30(3): 246-271. https://doi.org/10.1108/ebr-09-2015$\underline{0104}$

Kolodinsky, R. W.; Madden, T. M.; Zisk, D. S.; \& Henkel, E. T. 2010. Attitudes about corporate social responsibility: Business student predictors, Journal of Business Ethics 91(2): 167-181. https://doi.org/10.1007/s10551-009-0075-3 


\section{ENTREPRENEURSHIP AND SUSTAINABILITY ISSUES}

ISSN 2345-0282 (online) http://jssidoi.org/jesi/ 2020 Volume 8 Number 1 (September) http://doi.org/10.9770/jesi.2020.8.1(20)

Lauritsen, B. D.; \& Perks, K. J. 2015. The influence of interactive, non-interactive, implicit and explicit CSR communication on young adults' perception of UK supermarkets' corporate brand image and reputation, Corporate Communications: An International Journal 20(2): 178-195. https://doi.org/10.1108/ccij-09-2013-0065

Leonidou, L. C.; Leonidou, C. N.; \& Kvasova, O. 2013 Cultural drivers and trust outcomes of consumer perceptions of organizational unethical marketing behavior, European Journal of Marketing 47(3/4):525-556. https://doi.org/10.1108/03090561311297445

Lii, Y. S.; \& Lee, M. 2012. Doing right leads to doing well: When the type of CSR and reputation interact to affect consumer evaluations of the firm, Journal of Business Ethics 105(1): 69-81. https://doi.org/10.1007/s10551-011-0948-0

Maignan, I. 2001. Consumers' perceptions of corporate social responsibilities: A cross-cultural comparison, Journal of Business Ethics 30(1): 57-72. https://doi.org/10.1023/a:1006433928640

Mandhachitara, R.; \& Poolthong, Y. 2011. A model of customer loyalty and corporate social responsibility, Journal of Services Marketing 25(2): 122-133. https://doi.org/10.1108/08876041111119840

Marquina Feldman, P.; \& Vasquez-Parraga, A. Z. 2013. Consumer social responses to CSR initiatives versus corporate abilities. Journal of Consumer Marketing 30(2): 100-111. https://doi.org/10.1108/07363761311304915

Mohr, L. A.; Webb, D. J.; \& Harris, K. E. 2001. Do consumers expect companies to be socially responsible? The impact of corporate social responsibility on buying behavior, Journal of Consumer Affairs 35(1):45-72. https://doi.org/10.1111/j.1745-6606.2001.tb00102.x

Moreira, A. C.; Silva, P. M.; \& Moutinho, V. F. 2016. Differences between stayers, switchers, and heavy switchers: A study in the telecommunications service market, Marketing Intelligence \& Planning 34(6): 843-862. https://doi.org/10.1108/mip-07-2015-0128

Palihawadana, D.; Oghazi, P.; \& Liu, Y. 2016. Effects of ethical ideologies and perceptions of CSR on consumer behavior, Journal of Business Research 69(11): 4964-4969. https://doi.org/10.1016/j.jbusres.2016.04.060

Peloza, J.; \& Shang, J. 2011. How can corporate social responsibility activities create value for stakeholders? A systematic review, Journal of the academy of Marketing Science 39(1):117-135. https://doi.org/10.1007/s11747-010-0213-6

Pérez, A.; \& Rodriguez del Bosque, I. 2015. Corporate social responsibility and customer loyalty: exploring the role of identification, satisfaction and type of company, Journal of Services Marketing 29(1): 15-25. https://doi.org/10.1108/jsm-10-2013-0272

Russell, D. W.; \& Russell, C. A. 2010. Here or there? Consumer reactions to corporate social responsibility initiatives: Egocentric tendencies and their moderators, Marketing Letters 21(1): 65-81. https://doi.org/10.1007/s11002-009-9082-5

Sen, S.; Bhattacharya, C. B.; \& Korschun, D. 2006. The role of corporate social responsibility in strengthening multiple stakeholder relationships: A field experiment, Journal of the Academy of Marketing science 34(2): 158-166. https://doi.org/10.1177/0092070305284978

Valentine, S. R.; \& Bateman, C. R. 2011. The impact of ethical ideologies, moral intensity, and social context on sales-based ethical reasoning, Journal of Business Ethics 102(1): 155-168. https://doi.org/10.1007/s10551-011-0807-z

Wan, L. C.; Poon, P. S.; \& Yu, C. 2016. Consumer reactions to corporate social responsibility brands: the role of face concern, Journal of Consumer Marketing 33(1): 52-60. https://doi.org/10.1108/jcm-03-2013-0493 


\section{ENTREPRENEURSHIP AND SUSTAINABILITY ISSUES}

ISSN 2345-0282 (online) http://jssidoi.org/jesi/ 2020 Volume 8 Number 1 (September)

http://doi.org/10.9770/jesi.2020.8.1(20)

Daiva BENIULYTÉ is a master of marketing at Kaunas University of Technology (KTU). She is also visiting lecturer and the communication and marketing manager. Her research interests are related with corporate social responsibility, perceived corporate social responsibility by consumers, consumer ethical ideologies, consumer loyalty and social marketing.

ORCID ID: https://orcid.org/0000-0001-6235-0688

Beata ŠEINAUSKIENĖ is an Associate Professor at the School of Economics and Business of Kaunas University of Technology (KTU), Lithuania. She holds a PhD in Economics from KTU. She has research interests in the international marketing field with a particular focus on international marketing strategies of companies in the early stages of internationalisation. Her current research is focused on consumer behaviour issues linked to the causes and consequences of consumer's materialism. Since 2016, she leads a Consumer Materialism research cluster at KTU. She is a member of European Marketing Academy (EMAC).

ORCID ID: https://orcid.org/0000-0003-1791-0214

Aušra RŪTELIONĖ is Associate Professor at Sustainable Management Research Group at Kaunas University of Technology (KTU). She is the associate professor of Marketing and Consumer Research at the School of Economics and Business, KTU. Her research interests are related with sustainable consumer behavior, social marketing, consumer materialism, co-creation and consumer engagement, subjective well-being. Ausra has more than 20 years in R\&D and other projects (i.e. COST, H2020, EIT, EASME, Interreg, etc.) as the manager and/or researcher. She is a member of European Marketing Academy (EMAC).

ORCID ID: $\underline{\text { https://orcid.org/0000-0002-1013-0170 }}$

Make your research more visible, join the Twitter account of ENTREPRENEURSHIP AND SUSTAINABILITY ISSUES: @Entrepr69728810

Copyright (C) 2020 by author(s) and VsI Entrepreneurship and Sustainability Center This work is licensed under the Creative Commons Attribution International License (CC BY). http://creativecommons.org/licenses/by/4.0/

CC) (i) Open Access 